\title{
English Language Teaching Program of Universities: Does it cater for Multiple Intelligences of Students?
}

\author{
ReZa AbBasian AND Yaser KhajaVi \\ Faculty of Humanities, Islamic Azad University, Izeh Branch \\ Islamic Azad University, Izeh, Khoozestan, Iran
}

Received: 15 February 2011 / Accepted: 5 June 2011

ISSN: $1697-7467$

\begin{abstract}
The purpose of present study was to evaluate English language teaching program of Iranian universities to see to what extent MI theory has been implemented in educational system. As Marsh (1997) holds "curriculum starts as a plan; it only becomes a reality when teachers implement it with real students in a real classroom" (cited in Anthony, 2008: 77). Since teachers and textbooks are manifestations of education in curriculum, the study intended to investigate how the content of textbooks represents multiple intelligences. In particular, it sought to indicate if the textbooks covered all types of multiple intelligences in line with university disciplines of students. Also, in order to find if MI theory is implemented in the program, a series of semistructured interviews were conducted with university instructors of English. The aim of interviews was to find if instructors apply principles of MI in their classes. The results of this quantitative-qualitative study revealed that ELT textbooks covered a limited range of multiple intelligences i.e. mostly verbal/linguistics intelligence. In addition, the study indicated that MI principles are not applied in the English language classroom. Based on the views of instructors, some suggestions would be made regarding implementing MI in the English language curriculum. The results may be used as a guide for developing teacher education programs in Iran and other countries which are going to implement MI principles in their ELT curriculums. It is hoped that the findings will have an impact on policy makers as well as instructors' concerns about curriculum reform in universities.
\end{abstract}

Keywords: Multiple intelligences, ELT textbooks, English language teaching.

El currículo de inglés en las universidades iraníes: ¿tiene en cuenta las inteligencias múltiples de los alumnos?

RESUMEN: El propósito del presente estudio fue evaluar la Enseñanza de Inglés en el plan de estudios de las universidades iraníes para ver en qué medida la teoría sobre MI se ha implementado en su sistema educativo. Como sostiene Marsh, (1997): "el currículo se inicia como un plan, sólo se convierte en una realidad cuando los maestros lo ponen en práctica con alumnos reales en un aula real" (citado en Anthony, 2008:77). Puesto que los profesores y los libros de texto son manifestaciones de la educación en el currículo, el estudio pretendía investigar cómo el contenido de los libros 
de texto representan las Inteligencias múltiples. En particular, se intentaba indicar si los libros de texto cubrían todos los tipos de inteligencias múltiples en línea con las disciplinas universitarias de los estudiantes. Además, con el fin de averiguar si las MI se implementan en el plan de estudios, se realizaron una serie de entrevistas semiestructuradas con profesores universitarios de inglés a fin de determinar si se aplican los principios de las MI en sus clases. Los resultados de este estudio cualitativocuantitativo reveló que los libros de ELT cubren una gama limitada de las inteligencias múltiples es decir, sobre todo la inteligencia verbal/lingüística. Además, el estudio indicó que los principios de MI no se aplican en el aula de inglés. Sobre la base de las opiniones de los instructores, se hicieron algunas sugerencias sobre la aplicación de MI en el plan de estudios. En cuanto a la evaluación de libros de texto en términos de contenido, también se han ofrecido algunas sugerencias para mejorar el contenido de los mismos. Los resultados pueden usarse como una guía para el desarrollo de programas de educación docente en Irán y otros países que van a poner en práctica principios de salud mental en su plan de estudios. Se espera que los resultados tengan un impacto en los responsables políticos, así como las preocupaciones de los instructores sobre la reforma curricular en las universidades.

Palabras clave: Inteligencias múltiples, libros de texto, enseñanza de inglés.

\section{InTRODUCTION}

As $\mathrm{Wu}$ and Alrabha (2009) assert, one of the key factors which distinguishes modern and traditional methods of teaching is that modern methods attempt to take the individual differences of students into account in implementing their activities. Individual differences can influence the process of teaching/learning to a large extent. At present, it is not wise to think that all students are able to learn in the same way. Although there is a notion that everybody can learn, it does not mean that all students learn like one another. Just like chess players who win the games with different strategies and use different intelligences, they all are successful in their games, however, in different ways. As such, a considerable body of research investigates individual differences in relation to learning. One of the recent theories which take the individual differences of students into account in an efficient manner is multiple intelligences theory. Wu \& Alrabha (2009) affirm that the increasing tendency of teachers to Gardner's theory of multiple intelligences is coherent with learners' individual differences for enhancing learning in classroom. Similarly, Beceren (2010) asserts that by application of MI theory, a new path is opened for academics in syllabus design and curriculum development which considers individual differences and adopts the aptitudes by means of these principles creatively. Considering every student's specific intelligences, teaching activities should be accommodated to the needs and styles of students so as to facilitate the process of learning (Yenice \& Aktamis, 2010). Multiple Intelligences (MI) support teachers with individual specific potentials and consider them in teaching/learning conditions (Serin et al, 2009). It should be noted that multiple intelligences theory covered a long distance to prove that students should be taught based on their aptitudes (Lin, 2009). Ozdilek, (2010) proposes teaching based on Multiple Intelligences and believes that all of the students possess all of the intelligences in spite of the weaknesses and strengths in some of them. As a result, students can achieve success based on the intelligence types they have. Sozen et al. (2009) believe that from 
the publication of MI theory on, instructors have struggled to combine and apply the principles of multiple intelligence theory in curriculum development, syllabus design and teaching/ learning conditions. Although, there is a large and increasing literature on the role and efficiency of MI theory, there is paucity of research examining if MI principles have been included in foreign language teaching curriculum. The purpose of this study was to evaluate English language teaching curriculum at Iranian universities. As teachers and textbooks are cornerstones of education in curriculum, the study intended to investigate how the content of textbooks represents multiple intelligences. Additionally, the study strived to find if English language instructors consider principles of MI in their classes.

\section{REVIEW OF RELATED LITERATURE}

\subsection{Multiple intelligences theory}

Multiple Intelligence theory began to appear with the book "Frames of Mind: The Theory of Multiple Intelligence" written by Howard Gardner in 1983. Multiple Intelligence theory (Gardner, 1983, 1993, 1999) considers intelligence as a set of different aptitudes which are closely related to one another. As Yenice \& Aktamis (2010) assert, the theory of multiple intelligence creates a new path to consider individual differences in education and educational settings6. In favor of this view, Sauer (1998) holds that the commonality of Gardner's multiple intelligence theory in education led many teachers to take it as a basis from which to promote curriculum, syllabus and methodology (as cited in Wu \& Alrabha, 2009). Gardner classifies individual intelligences to eight ones. Armstrong also describes the eight types of intelligences as the following:

1. Linguistic Intelligence: The capability to apply language in all four skills; listening, reading, and speaking (e.g., as a reporter, lecturer or politician), writing (e.g., syntactically, semantically, pragmatically, conversationally and meta-linguistically). Moreover, it means to have a superior power of communicative competence.

2. Logical-Mathematical Intelligence: the talent to employ numbers skillfully (e.g., as an accountant, statistician, or mathematician) and to present logical justifications (e.g., as an engineer, programmer, or scholar). This aptitude includes sensitivity to propositions (if then, cause-effect), logical statement, patterns and relations. Activities like categorization, arithmetical computation, generalization, and inference deal with this intelligence.

3. Musical Intelligence: The capacities to generate, differentiate, distinguish, scrutinize, synthesize, and compose rhythm, melody, tone and harmony of musical pieces fit in this intelligence.

4. Spatial Intelligence: The ability to realize, visualize and configure visual-spatial world accurately (e.g., as a guide or hunter) and to implement transformations upon those realizations (e.g., as an architect or designer). The aptitude also has close relationship with color, line, shape, form and space.

5. Bodily/Kinesthetic Intelligence: expertise to use one's body to express feelings and opinions (e.g., as an actor or gymnast) and deliberation to make handicrafts or handmade goods. This aptitude also includes deliberate physical skills such as coordination, balance, dexterity, strength and flexibility. 
6. Interpersonal Intelligence: The expertise in recognition and discrimination of other people's aims, motivations, interests, and feelings that are implemented by sensitivity to voice, gesture, facial expression and also the ability to answer actions functionally and effectively.

7. Intrapersonal Intelligence: The ability to have self-awareness and self- recognition to act accordingly and to know ones' own weaknesses and strengths that contributes to self-esteem, self- understanding and self-discipline belong to this category of intelligence.

8. Naturalistic Intelligence: The capacity to recognize, classify, tell apart and recognize live species, ecological phenomena and inorganic objects.

\subsection{Multiple intelligences and English language teaching}

\subsubsection{General theoretical framework of MI theory for TEFL}

With emergence of Humanism and concepts of whole person and communicative approach, traditional teacher-centered classes gave their way to learner-centered teaching. Also, a wave of innovative methods emerged in the realm of English language teaching. These new methods such as Silent way, Natural approach, Suggestopedia and alike focused mostly on the learners and their affective emotions and feelings (Richards \& Rodgers, 2001). As Chen (2005) rightly contends, multiple intelligences can have many benefits in implementing the principles of innovative methods. For example, total physical response emphasizes on bodily movements (bodily/kinesthetic intelligence). suggestopedia uses music in a large part (musical intelligence). In addition, silent way engages students' inner feelings (intrapersonal intelligence). Cooperative language learning emphasizes group work which can be linked to interpersonal intelligence in MI theory. Also as Nunun (1988) maintains, learners' needs have a vital role in designing a learner-centered curriculum. As MI theory draws on individual differences of learners, it can propose a valid base from which to proceed to needs of language learners. It seems that, at present time, English language teaching is open to implementing the principles of MI in the process of teaching and learning more than any time.

\subsubsection{Previous studies regarding $M I$ theory and English language teaching}

Puchta \& Rinvolucri (2005) assert that students' motivation, to some extent, rely on how they feel addressed in the atmosphere of the class and on meaningfulness of the activities for them. In a class which is merely focused on linguistic exercises, those who are powerful in linguistic intelligence will come to better outcomes while others may not do so. Then diverse exercises will activate all of the students who are strong in other intelligences other than linguistic and will enhance their interest in the subject and will attract their attention to follow the course of instruction in order to find out more about it. Educational contents and contexts should provide a suitable ground to strengthen those intelligence types that are weaker (Heacox, 2002).

Multiple intelligences have been studied in relation to a number of variables relating to language learning and teaching. Some of these studies investigate MI in relation to 
language learning strategies and language components. For example, Razmjoo et al. (2009) strived to find the relation between multiple intelligences (MI), vocabulary learning knowledge and vocabulary learning strategies among EFL learners. The participants were TEFL students in Shiraz Azad University. The results indicated a close relationship between MI and vocabulary knowledge. Moreover, linguistic and natural intelligence had great effects on the prediction of vocabulary learning. Regarding the relationship between multiple intelligences and vocabulary strategies, among five groups of strategies, determination, social and memory strategies had a close connection with several intelligence types.

In another study in this line, Saricaoglu \& Arikan (2009) studied the relationship between students' gender and intelligence types. The relationship between particular intelligence types and students' success in grammar, listening and writing in English as a foreign language and the relationship between parental education and students' types of intelligences were also studied. Sample of study consisted of one hundred fourteen students who studied at the school of foreign languages of Erciyes University. Multiple intelligences profiles of students were measured through MI Inventory for Adults. The findings did not show any significant differences in the intelligence types of participants in relation to gender. However, positive relationship was found between gender and linguistic intelligence. Negative but significant relationships were found between success in students' test scores in grammar and bodily-kinesthetic, spatial, and intrapersonal intelligences whereas the relationship between musical intelligence and writing was found to be significant and positive. Finally, no significant relationship was found between parental education and students' intelligence types.

Akbari \& Hosseini (2008) examined the possible connections between the use of language learning strategies and multiple intelligences among ninety Iranian EFL students. In order to measure multiple intelligences, MIDAS, a commercially designed instrument for assessing MI, was applied. Strategy use Inventory for Language Learning Learners' SILL was utilized for measuring strategy use of participants. The results indicated significant relationships between the use of language learning strategies and MI scores of participants. Bodily/Kinesthetic intelligence indicated significant relationship with memory learning strategies. However, no significant correlation was found between musical intelligence and any aspect of strategy use. These studies investigated MI in relation to students; however some other studies have investigated MI in ELT textbooks.

In terms of English language textbooks, up to now, few books have been designed and published to comprise the principle of MI theory in language teaching domain; likewise, no thorough ELT book has been designed to exert MI theory on its content completely. As Riazi \& Mosallanejad (2010) maintain "constant evaluation of textbooks to see if they are appropriate is of great importance" (p. 2). The number of studies which investigate MI theory in language textbooks is very limited and they are mostly conducted in the current decade. One of the first studies in this series was conducted by Snider (2001) who ran a foreign language textbook assessment considering MI theory. Ten famous, first year German college textbooks were evaluated to recognize different activities which dealt with learners' multiple intelligences and also the range of this engagement. His study indicated that just a limited range of exercises used in the syllabi dealt with confined numbers of multiple intelligences. He proposed that MI theory should be taken 
as a criterion for involving all kinds of intelligences in language learning exercises and activities.

Another evaluation of English language teaching textbooks and materials in light of multiple intelligences theory was conducted by Botelho (2003). He assessed six English textbooks considering MI theory to know the range of activities which dealt with learners' intelligences. Some interviews were conducted with two groups of ELT teachers, native Brazilians and nonnative ones, to know how much they were familiar with multiple intelligences theory, teaching contexts, and selection of textbooks and materials. The study indicated that they knew and used multiple intelligences theory in their educational setting and activities. Concerning textbooks and materials, the findings showed that the exercises and activities revolved mainly around four types of intelligences i.e., verbal/ linguistic, intrapersonal, spatial/visual and interpersonal.

Yet in another study, Alghazo et al. (2009) studied multiple intelligences in the social studies, Arabic and English books. To implement the study, the researchers created an instrument which included thirty questions with five categories; each one belonged to one type of the multiple intelligences namely visual, aural, physical, social and environmental. The research was done by evaluating all the three books (social studies, Arabic and English). The results of the study indicated that visual intelligence is the most used intelligence in all three books and grades; likewise, the least used one was physical intelligence in the social books and environmental intelligence in the English and Arabic books. The results of the study showed differences in the arrangement of all types of intelligences in all the grades. There existed difference in availability of these multi intelligences in all the three books and in support of the social studies books.

In a recent study, Kirkgoz (2010) studied English textbooks designed by non-natives for primary level in Turkish state schools to determine the extent they responded to multiple intelligences. Based on the principles of MI theory, a checklist was designed to specify the extent to which textbooks activities and tasks followed the principles. The results showed that the intelligence profiles of English textbooks were mainly Verbal/ Linguistic and Visual/Spatial. The least used intelligence type was natural one which was only provided in activities of grade four and five textbooks. The rest of intelligence types were fairly distributed in the textbooks activities and tasks. As the review of literature suggests, unlike the role of MI in education, there are few studies investigating the implementation of multiple intelligences activities in ELT textbooks. In addition, previous studies have not considered the textbooks and intelligences in relation to users of these materials to see if the intelligences used are in line with intelligences of users. To best knowledge of the authors, there is no published research examining English for specific purposes (ESP) textbooks in the light of multiple intelligences in Iran. Also, there is paucity of research examining implementation of MI in curriculum especially in Asian countries which mostly follow traditional methods of education. As such, present study aims to address this gap in the literature.

\subsection{Purpose of the study and research questions}

The purpose of present study was to evaluate English language teaching program of Iranian universities to see to what extent MI theory was implemented in the educational 
system. The study intended to investigate how the content of textbooks represented multiple intelligences. In particular, it sought to indicate if the textbooks cover all types of multiple intelligences in a proper manner. In addition, the study sought to find if English instructors consider principles of MI in their classes. The study, therefore, aims to find answers to the following questions:

1. What is the multiple intelligences profile of ESP textbooks taught at Iranian universities?

2. To what extent university disciplines of students have been taken into account in designing activities?

3. Are university instructors familiar with multiple intelligences theory?

4. Do university instructors utilize MI principles in their classes?

\section{Methodology}

\subsection{Participants}

Thirty university instructors who taught English in open and state universities of Iran were interviewed. Researchers sent emails to sixty seven instructors, from whom thirty accepted to participate in the interviews. The work experience of participants ranged from 1 to 15 years in teaching English at Iranian universities. In order to find if English instructors consider principles of MI in their classes, a series of semi-structured interviews were conducted with instructors.

\subsection{Materials}

In order to fulfill the aims of the study, eighteen current ESP textbooks that are being used in Iranian universities were selected by cluster sampling. The rational behind selecting ESP textbooks was that they had not been studied in previous studies. Additionally, it was possible for us to consider intelligences in comparison with university disciplines of students. The textbooks selected are widely taught in different state and open universities in Iran. These textbooks are published by SAMT publication which is a governmental organization that publishes textbooks to be taught at universities. The list of analyzed textbooks is as follows:

English for the students of Persian Literature II

English for the students of accounting

English for the students of theology and Islamic studies

English for the students of Agriculture

English for the students of Civil Engineering

English for the students of Medicine

English for the students of Physics

English for the students of Power \& Electronics Engineering

English for the students of Power, Electronics, Control \& Communications

English for the students of Mechanical Engineering, Fluid Thermal Approach 


\author{
English for Physical Education \\ English For the Humanities I \\ English for the students of General Psychology \\ English for the students of Archaeology \\ Legal Texts (Criminal Law) A Text Book For Law Students. \\ English for the students of Applied Physics \\ English for Computer science students \\ English for the students of counseling
}

Textbooks were classified according to the nature of the courses. The groups identified were Humanities (Literature, Law, Theology, Archeology), (Mathematics, physics, engineering...), physical education, and psychology and counseling. The researchers used the content analysis approach in this study to investigate the types of multiple intelligences in the mentioned textbooks.

\title{
3.3. Procedure
}

Textbooks were analyzed in order to know the percentage of activities that employ each of the eight intelligences. Activities and passages of ESP textbooks were extracted and tabulated. Then the type of intelligence which was influenced by each activity was identified. At last, the number of incidence of each activity and its percentage were determined. Using a coding scheme, all parts of textbooks were coded in terms of type of activity and the type of intelligences that they engaged. In addition, the frequency of each activity and intelligence was calculated for each book and also for the whole group of books. Two raters evaluated the materials. The reliability of the coding scheme was calculated through inter and intra-coder reliability. Intra-coder reliability was 0.96 and the inter-coder reliability was 0.93 .

\subsubsection{Coding schemes for textbooks}

A coding scheme for classifying and evaluating the content of textbooks using MI theory was developed. Gardner's definitions of different types of multiple intelligences were carefully studied and the key word examples were extracted and used. The coding scheme represented eight types of intelligences and their manifestations in the activities.

The coding categories were labeled as: VL for verbal/linguistic; LM for logical/ mathematical; SV for spatial/visual; BK for bodily/kinesthetic; $\mathrm{M}$ for musical; IR for interpersonal; IA for intrapersonal and $\mathrm{N}$ for naturalist intelligence. Based on Botelho (2003), some elements were taken into consideration when identifying the intelligences in the activities, especially the type and description of the activity, the elements that were part of the activity (such as pictures, graphs and realia), the techniques and materials necessary for doing the activity, and the skills being practiced.

\subsubsection{Interviews}

Interviews were conducted with regard to implementation of MI in university classes. The rational behind using interview was those interviews assess instructors' ideas in a 
more thorough manner compared with questionnaires. According to an interview scheme, interviewers asked general and specific questions regarding activities that instructors used in their classes. Additionally, they were asked about concept of multiple intelligences to see to what extent they were familiar with the theory and its principles. Also views of instructors were assessed relating to how they implemented MI principles in their classes.

\section{Data analysis}

The textbooks were analyzed based on the developed coding scheme by identifying the intelligences incorporated in each activity in the eighteen books selected including extra activities. After collecting the data, the results were analyzed. The units in the eighteen textbooks analyzed are divided into sections, which are usually labeled clearly. The parts differ a little from one book to another; however, they normally focus on the two skills i.e. reading and writing as well as grammar and vocabulary. In this study, the concept of "intelligence" in relation to textbooks refers to the occurrence of elements in the textbook exercises which promote the intelligences in language learners. The results obtained included the total number of activities in eighteen books, the sum of occurrences of each intelligence in the books, and the percentage of occurrence of each intelligence in all the books.

\subsection{Analysis of Interviews}

After conducting interviews, analysis of interviews started so as to determine prominent features out of the data and to shift from description to explanation. In the first step, some codes were assigned to the interview data to determine emergent structure. After initial coding, the process of focused coding was conducted in which the researchers searched for repeating ideas (the similar ideas expressed by different interviewees) and important topics that associated with codes, while removing less useful codes. Finally, the ultimate codes were classified into themes. To sum up, we seek to make out patterns and themes from a diversity of records and to find relationships and linkages across the data collected.

\section{RESULtS}

\subsection{Findings of textbook analysis}

The textbooks were analyzed in order to identify the intelligences that were included in the ESP books taught at universities. The research determined the textbook intelligence profiles and the extent to which the textbooks engage MI in learners. The results from the analysis of all textbooks are presented and discussed. 
RQ1. What is the multiple intelligences profile of ESP textbooks taught at Iranian universities?

Table 1. Humanities (Literature, Law, Theology, Archeology).

\begin{tabular}{|c|l|c|c|}
\hline Multiple Intelligences & $\begin{array}{c}\text { Frequency of } \\
\text { Activities }\end{array}$ & Percentage \\
\hline 1 & Linguistic Intelligence & 4500 & 94.3 \\
\hline 2 & Logical mathematical & 62 & 1.2 \\
\hline 3 & Spatial Visual & 50 & 1.04 \\
\hline 4 & Bodily Kinesthetic & 0 & 0 \\
\hline 5 & Musical & 0 & 0 \\
\hline 6 & Interpersonal & 80 & 1.6 \\
\hline 7 & Intrapersonal & 70 & 0.2 \\
\hline 8 & Naturalist & 10 & $100 \%$ \\
\hline & Total & 4772 & \\
\hline
\end{tabular}

A total of 4772 activities were analyzed for humanities textbooks. The occurrence of each intelligence was counted and the percentage of each intelligence was identified. Table 1 indicates the percentage of occurrence of each intelligence in the textbooks analyzed in this study. As shown, the profile of the English textbooks was mostly verbal/ linguistic i.e. from among 4772 activities 4500 (94.3\%) activities presented linguistics intelligence. After linguistics intelligence, logical intelligence $62(1.2 \%)$, spatial /visual 50 (1.04\%), bodily/kinesthetic $0 \%$, musical $0 \%$, interpersonal 80(1.6), intrapersonal, 70 (1.4) and naturalist $10(0.2)$. The results are shown in figure 1.

Table 2. Engineering Sciences, Mathematics, Physics.

\begin{tabular}{|c|l|c|c|}
\hline Multiple Intelligences & $\begin{array}{c}\text { Frequency of } \\
\text { Activities }\end{array}$ & Percentage \\
\hline 1 & Linguistic Intelligence & 10610 & 97.2 \\
\hline 2 & Logical mathematical & 113 & 1.03 \\
\hline 3 & Spatial Visual & 56 & 0.51 \\
\hline 4 & Bodily Kinesthetic & 0 & 0 \\
\hline 5 & Musical & 0 & 0 \\
\hline 6 & Interpersonal & 60 & 0.54 \\
\hline 7 & Intrapersonal & 78 & 0.71 \\
\hline 8 & Naturalist & 21 & 0.19 \\
\hline & Total & 10913 & 100 \\
\hline
\end{tabular}

As table 2 illustrates, for the next group of books related to Engineering Sciences, Mathematics, Physics 10913 activities were analyzed. Table 2 shows the percentage of occurrence of each intelligence in the textbooks. From among 10610 activities (97.2\%) activities presented linguistics intelligence. After linguistics intelligence, logical intelligence $113(1.3 \%)$, spatial/visual $56(0.51 \%)$, bodily/kinesthetic $0 \%$, musical $0 \%$, interpersonal 60 
$(0.54 \%)$, intrapersonal, $78(0.71 \%)$ and naturalist $21(0.19 \%)$. The percentages of intelligences are illustrated in figure 2.

Table 3. Physical education.

\begin{tabular}{|c|l|c|c|}
\hline & Multiple Intelligences & $\begin{array}{c}\text { Frequency of } \\
\text { Activities }\end{array}$ & Percentage \\
\hline 1 & Linguistic Intelligence & 950 & 86 \\
\hline 2 & Logical mathematical & 35 & 3.17 \\
\hline 3 & Spatial Visual & 46 & 4.17 \\
\hline 4 & Bodily Kinesthetic & 0 & 0 \\
\hline 5 & Musical & 0 & 0 \\
\hline 6 & Interpersonal & 32 & 2.90 \\
\hline 7 & Intrapersonal & 22 & 1.99 \\
\hline 8 & Naturalist & 16 & 1.45 \\
\hline & Total & 1101 & 100 \\
\hline
\end{tabular}

A number of 1110 activities were analyzed for physical education textbooks. Table 3 and figure 3 indicate the percentage of occurrence of each intelligence in the textbooks. From among 1110 activities $950(86 \%)$ activities presented linguistics intelligence. After linguistics intelligence, logical intelligence 35 (3.17\%), spatial/visual 46 (4.17\%), bodily/ kinesthetic $0 \%$, musical 0\%, interpersonal 32 (2.90\%), intrapersonal, $22(1.99 \%)$ and naturalist $16(1.45 \%)$.

Table 4. Psychology and Counseling.

\begin{tabular}{|c|l|c|c|}
\hline Multiple Intelligences & $\begin{array}{c}\text { Frequency of } \\
\text { Activities }\end{array}$ & Percentage \\
\hline 1 & Linguistic Intelligence & 430 & 89.5 \\
\hline 2 & Logical mathematical & 10 & 2.08 \\
\hline 3 & Spatial Visual & 20 & 4.16 \\
\hline 4 & Bodily Kinesthetic & 0 & 0 \\
\hline 5 & Musical & 0 & 0 \\
\hline 6 & Interpersonal & 16 & 3.33 \\
\hline 7 & Intrapersonal & 8 & 1.66 \\
\hline 8 & Naturalist & 0 & 0 \\
\hline & Total & 484 & 100 \\
\hline
\end{tabular}

A total of 484 activities were analyzed for general psychology and counseling textbooks. As table 4 illustrates, from among 484 activities $430(89.5 \%)$ activities presented linguistics intelligence. After linguistics intelligence, logical intelligence 10 (2.8\%), spatial/ visual $20(4.16 \%)$, bodily/kinesthetic $0 \%$, musical $0 \%$, interpersonal $16(3.33 \%)$, intrapersonal, $8(1.66 \%)$ and naturalist $0(0 \%)$. 
RQ2. To what extent university disciplines of students have been taken into account in designing activities?

As the tables and figures clearly show, the disciplines of students have not been considered. It is expected that based on the engineering and mathematics textbooks, logical mathematical intelligences be included more than other types, however, only $1.03 \%$ of activities engage this type of intelligence. In counseling and psychology textbooks which should focus more on interpersonal intelligences, only $3.3 \%$ of activities foster this type of intelligence. Surprisingly, as for physical education textbooks, no activities engage bodily/ kinesthetic intelligence. The focus of most of the activities is on linguistics intelligence. It seems that the authors of these textbooks have considered all of the students the same and have not taken their individual differences into account. This is clearly against the principles of MI theory.

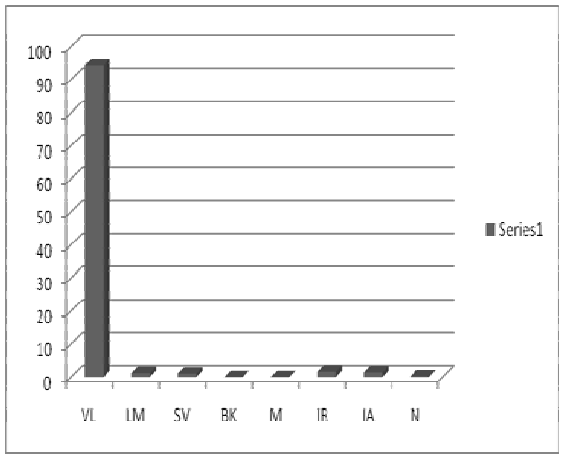

Figure1: Percentages of MI in activities of Humanities (Literature, Law, Theology, Archeology)

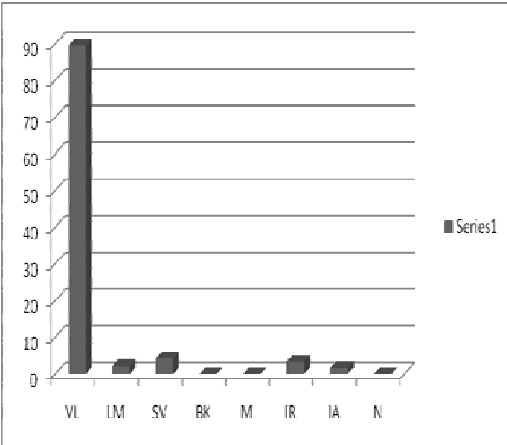

Figure2: Percentages of MI in activities of Engineering Sciences, Mathematics, Physics

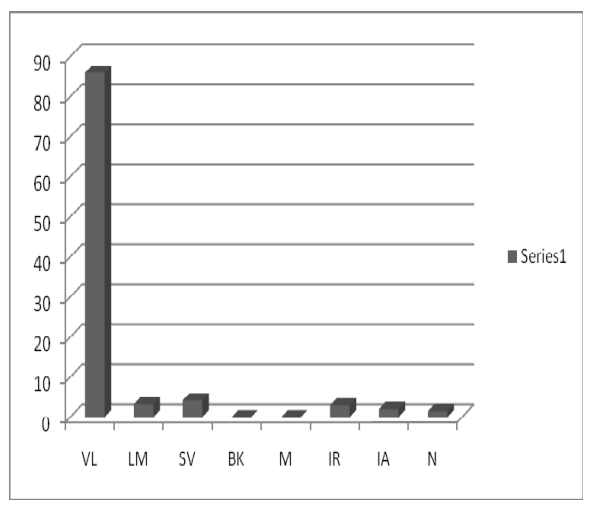

Figure 3: Percentages of MI in activities of Physical Education textbooks

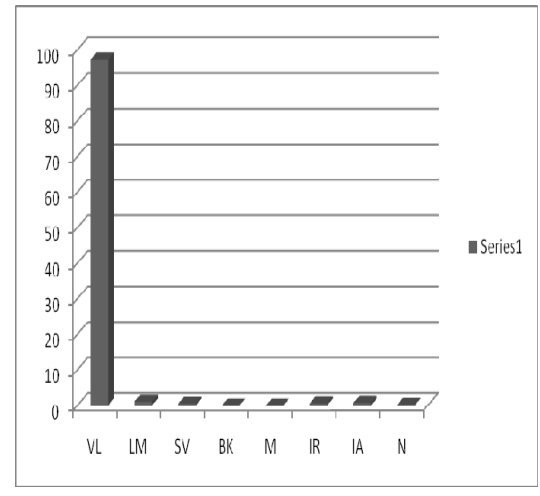

Figure 4: Percentages of MI in activities of Psychology and counseling textbooks 


\subsection{Findings of Interviews}

The two research questions which investigated the knowledge and implementation of MI in the classroom were as follows:

RQ3. Are university instructors familiar with multiple intelligences theory?

RQ4. Do university instructors consider MI principles in teaching their classes?

In order to answer these two research questions, a series of semi structured interviews were conducted with university instructors who taught English language courses at universities. They had long experience in teaching English at university level. A number of questions were posed in the interviews. Some of the questions and some common answers are presented here.

\section{Are you familiar with MI theory?}

Regarding the first question investigating if instructors were familiar with MI theory; most of the instructors were familiar with this theory more or less. All university instructors understood the concept of multiple intelligences. They had studied some inadequate materials regarding $\mathrm{MI}$ in their training. However, they believed that materials in their studies were not enough for mastery of MI.

We studied a chapter of a book in our methodology course regarding MI. Now I just remember the overall theory with its categories but I don't remember the details. In those days, MI was not popular as present. (One of the interviewees).

They were familiar with the fact that MI theory tries to account for individual differences and opposes unitary hypothesis of IQ. They generally knew that this theory is proposed by Howard Gardner.

\section{Could you please explain about principles of MI?}

Few instructors were able to explain principles of MI in a methodical manner. Others were partly cognizant of main principles and classifications. Some of the university instructors had some vague understanding of MI principles. They were not much familiar with different types of intelligences in the theory. They mostly elaborated on three to four types of intelligences and could not explain entire ramifications and examples of the theory. One interesting thing was that most of the instructors could not mention how it is possible to engage the intelligences.

\section{Do you like to implement MI principles in your classes?}

The interviewees showed great interest in applying new methods for motivating students. In terms of methods that instructors used in their classes, they said that they mostly use traditional methods of teaching. The activities they implemented in the classroom 
show this reality clearly. Some of the instructors believed that they are not confident in using MI principles. Most of them traditionally used GTM or behaviorist approach to teach the language.

In my ESP classes, I sometimes ask my students to translate English texts into Persian. This will help them a lot in passing their exams and reading English language texts relating to their field of study.

As they had limited knowledge of MI, they could not apply MI in their classes. Almost, all of the instructors held that they do not use MI principles in a conscious manner. They noted that may be they sometimes use the principles in an unconscious manner.

\begin{abstract}
MI is a good theory for learning but I don't know how to use it in English language teaching. I think that there is much gap between theory and practice. For example, we know that learners have a variety of intelligences but the question is that how we can tap those areas.
\end{abstract}

The responses of instructors clearly showed that they do not use activities which reinforce multiple intelligences of students. For example, instructors maintained that they utilize group work in a limited manner. The participants held that implementing new theories like MI in teaching required much more time and motivation on the parts of instructors and learners. Most of the instructors believed MI could help students become more aware of their weaknesses as well as their strengths and improve those weak areas.

Some instructors questioned the feasibility of trying to use all intelligences in their classrooms. They believed that all the intelligences should be targeted during teaching; however, the use of anyone's intelligence should be based on its ability to support the aims of that lesson. The use of an approach or activity should be attuned to the nature of the lesson. One instructor said that planning, designing, and implementing a variety of MI teaching and learning activities while teaching require high levels of vigor and vast amounts of time and energy.

\title{
4. What problems instructors are faced with in implementing MI in their classes?
}

Generally instructors felt that some constraints in the curriculum do not allow them use these principles in their teaching. These constraints ranged from shortage of time to lack of suitable facilities in the educational context. Also most of the interviewees held that textbooks are center of education in the program and this leads to hindering creative methods like MI theory. They maintained that there is not enough space in curriculum for implementing novel ideas and behavior.

I have to stick with the syllabus and the coursebooks because the time of semester in very limited and I should design exams based on the materials presented in the textbooks. If I want to go beyond the textbooks and present some other materials, it will take a long time. We have to consider these constraints; otherwise there will be many problems in our way. 
Some instructors felt that lack of motivation to use new methods is another factor that MI principles are not used. They believed that MI has remained as a theory and its principles have not been implemented in English language teaching. They related this to many aspects. They generally believed that practical aspect of MI theory has been ignored in foreign language teaching and much more attention should be devoted to applying MI in the curriculum. Some instructors asserted that students would be motivated when their styles are touched upon. They maintained that MI can account for individual differences of students. They proposed that special courses can be included in teacher training courses for teaching MI theory and applications in English language teaching.

They maintained that these courses should try to teach instructors how to apply MI principles in their classes.

Regarding ESP courses and textbooks, they believed that materials have been prepared in the same style because they are published by SAMT publication. They were not satisfied with the materials in the textbooks.

They are mostly out dated. They fall short to motivate and encourage students.

\section{Do you believe that English language program consider individual differences?}

Except for one interviewee, all of the other instructors felt that individual differences of students have not yet been taken into account in the program. Some of the instructors asserted that a reform should be done in the curriculum based on new theories and methods in education in order to reflect on individuals' needs. In doing so, they mentioned the role of research in the curriculum and its efficiency in designing modern courses and materials.

I don't think that there have been thorough studies investigating the efficiency and success of present English language program. We have been faced with a vicious circle and there are few attempts for alleviating the problems. The first step in this way should be extensive research in this area.

Generally, instructors were in favor of using MI principles in classroom; however, they could not do this in practice due to lack of knowledge or limitations in the program.

\section{Discussion}

The purpose of present study was to evaluate English Language teaching program at Iranian universities to see to what extent MI theory has been implemented in the educational system. Two manifestations of the program i.e. instructors and textbooks were analyzed. The results revealed that these textbooks covered a limited range of multiple intelligences i.e. mostly verbal/linguistics intelligence. Also the authors of ESP books have not taken the disciplines of students into account in designing the books. As the findings clearly show more than $90 \%$ of activities in the textbooks involve verbal/ linguistics intelligence. In other words, a limited number of activities challenge intelligences 
like intrapersonal or interpersonal and spatial intelligences which are mostly less than $5 \%$. Furthermore, no activities in the books addressed musical and bodily/kinesthetic intelligences. With regard to the compatibility of textbooks materials with the students' fields of study, it was found that students' disciplines have not been taken into account in designing activities e.g. for books related to mathematics and engineering, there are a limited number of activities fostering logical/mathematical intelligence i.e. less than 2 percents. Additionally, there are no activities in the physical education textbooks addressing bodily/kinesthetic intelligence. Some textbooks have pictures and or photographs that illustrate situations presented in the books such as, reading passages or vocabulary which foster spatial intelligence. However, there are few tables, graphs, and graphic organizers especially for vocabulary tasks in the textbooks. The results are in line with previous studies (see Alghazo et al., 2009; Snider, 2001; Botelho, 2003) in that in all of these studies verbal/ linguistics intelligence was the dominant intelligence. As such, some changes should be made in ELT textbooks in order to engage other intelligences too.

In doing so, the usage of pictorial representations for catering spatial visual intelligence can be helpful. Furthermore, team working tasks can engage interpersonal intelligence. In order to apply logical mathematical intelligence, one may use guessing ability of learners to recognize the objects or materials. Making students think about their lives and explain their own personal beliefs and experiences with learning would strengthen their intrapersonal intelligence. Also, logical controversial debates of the students in pair and group not only enhance logical/mathematical intelligence but also interpersonal intelligence. Pictures and images could strengthen spatial visual intelligence. It should be said that games, role plays and some dialogues may engage more than one intelligence of the learners.

The results may lead to better understanding of the learning process even more than the intelligence area, and some of the feedbacks and interactions make you surprised and delighted. As Armstrong (2003) asserts, education should be connected to the environments that language skills are fed and supported with art, music, natural phenomena, logical analyses, films, narratives, social issues, and other variant nutrients. These principles can be used for designing activities for textbooks.

With regard to the questions addressing the implementation of MI in classroom, the results revealed that MI principles are not implemented in the ELT classrooms. As such, to make situation more favorite, some strategies can be suggested. A suitable plan should be designed to specify the roles of syllabus designers, teachers, students and educational managers in specific stage of learning and teaching in the curriculum based on individual differences of students. Syllabus designers and curriculum developers should create situations that enhance cognitive skills and consequently multiple intelligences to a higher degree. Finally, material development is an expertise that possesses a strong foundation, so authors of the textbooks should include those principles and findings while writing and revising books.

In addition, there would be a good idea to include an MI course for pre-service and in-service teachers and instructors. In these courses, special attention should be paid to how to implement MI principles in language classrooms. In addition, useful practicum classes can be very promising. One of the techniques that is to the linking of the learners, instructors and researchers is the application of multimedia in ELT syllabus, and to get benefit from all of the intelligences via deployment of some activities which foster 
intelligences. The first step is to design an activity, and the next one is to determine the type of media to be used. Then, the adequate amount of time should be assigned to each activity to manage and cover all of the constituent parts of the syllabus without time deficiency and loss. In order to engage other intelligences of students, it is well to assign time for the students to converse to each other about their inner processes occurred in the lessons.

Some instructors held that they do not know in which intelligences their students are competent so as to gear their teaching to that area. It would be very promising that at the outset of any program e.g. before entering BA level, strengths and weaknesses of students' MI be identified. This can be achieved simply through administrating MI scales like MIDAS in a short matter of time.

According to the viewpoints of university instructors, English teaching program is not flexible enough to account for individual differences among students. It is vital that policy makers and program developers make some necessary changes in the program and syllabus of English language courses in order to take multiple intelligences of students into account. The findings of interviews revealed that generally instructors agree with some changes in the methods that English is taught in universities. As such, more modern trends in teaching should be employed in teaching English to students. Another finding based on the perceptions in the interviews is that whereas instructors are interested in the MI theory and its principles, they do not know how to take these principles into action. It is the responsibility of MI specialists to make implications of this theory more applicable for instructors. In doing so, some ideas which connect theory to practice should be developed. Although there are a number of textbooks which do so, this number in teaching language skills is limited.

In terms of activities which can be done in the classroom, pair work and group work are the most common types of activities that generate interaction among students and enhance the interpersonal intelligence. Interpersonal intelligence can be enhanced in several types of activities e.g. speaking, listening, and reading even in writing and grammar exercises. In grammar exercises, for example, learners usually work alone; instructors can ask learners to work in pairs or groups to compare their answers and check exercises. Some activities that enhance the LM intelligence are matching, guessing/making predictions, ranking, and using statistical information with graphs/percentages. The most common activities for the BK intelligence are role plays and mime.

It is worth noting that in incorporating MI in the classroom, cultural differences of students in different regions should be considered. For example, Asian students are not similar in terms of cultural matters like individual identity or group identity compared with European students. So for classroom activities like group work, these differences should be considered.

In summary, if we are to take multiple intelligences seriously, then educational settings must set up a meaningful context for problem solving; it must give chances to students to practice using a variety of intelligences; it must construct self-esteem by assisting students build up precise and complete picture of their capabilities and it must create evaluation situations that smooth the progress of this trend. 


\section{Conclusion}

Present study suggests that the program manifestations like instructors teaching and textbooks activities revolve around linguistic intelligence and the role of other type of intelligences is almost neglected i.e. just limited numbers of intelligences are applied through materials and instructors' teaching. It is clear that textbook writers should find ways to challenge all of the intelligence types to meet the requirements of the learners and to adopt and utilize all of intelligences based on the disciplines of students.

In English language classes, instructors should remember that all students have diverse intelligences; however, intelligences differ in their strengths among different individuals. As instructors, we should utilize teaching methods and activities to reinforce students' intelligences. Each student's learning style and intelligences should be paid enough attention and reinforcement. Also attempts should be made to improve the knowledge of instructors about MI and other trends accounting for individual differences of students. The teachers' attitudes toward students' abilities will influence the ways they present materials to their students and also the methods they evaluate students' capacity. If instructors and officials can provide opportunities for students' learning based on their interests, aptitudes, and intelligences, students will be able to show their strengths and to improve their motivation which will lead to confidence in pursuing their education. Thus, it is highly necessary to develop a curriculum that caters for the undeveloped intelligences and strengthens the developed ones. In fact, this efficient curriculum based on MI theory can be used for students with diverse intelligences. For the implementation of MI, it is clear that a more student-centered curriculum is necessary. The results of the study may be used as a guide for developing teacher education programs in Iran and other Asian countries which are going to implement MI principles in their ELT curriculums. It is hoped that the findings will have an impact on policy makers as well as instructors' concerns about curriculum reform in universities. It should be noted that, this study is a preliminary one. Therefore, further research investigating ELT curriculums in other countries would shed more light on designing ELT programs in universities. It should be noted that due to shortage of time and limitation in participation of the instructors in the interviews, it was not practical to administer interviews with a larger sample. Further researches and studies with more informants would come to more precise results and would shed more light on this issue.

\section{ACKNowledgment}

The authors are very grateful to Professor Mario Rinvolucri and Dr. Thomas Armstrong for their constructive comments in classifying activities and passages to MI categories. The research project was funded by the Islamic Azad University, Izeh branch, Iran (Project No: 13659). 


\section{REFERENCES}

Akbari, R., \& Hosseini, K. (2008). "Multiple intelligences and language learning strategies: Investigating possible relations", in System, 36: 141-155.

Alghazo, K., Obeidat, H.H., Al-trawneh, M., Alshraideh, M. (2009). "Types of multiple intelligences in social studies, Arabic and English language textbooks for the first three grades", in European Journal of Social Sciences. 12(1): 7-20.

Anthony, L. W. L. (2008). "Teacher Concerns about Curriculum Reform: The Case of Project Learning", in The Asia-Pacific Education Researcher. 17: 75-97.

Armstrong, T. (2001). Multiple Intelligences in the Classroom. Alexandria, VA: ASCD.

Armstrong, T. (2003). The multiple intelligences of reading and writing: making the words come alive.

Beceren, B. Ö. (2010). "Determining multiple intelligences pre-school children (4-6 age) in learning process", in Procedia Social and Behavioral Sciences, 2: 2473-2480.

Botelho, M. (2003). Multiple Intelligences Theory in English Language Teaching and Analysis of Current Textbooks, Materials and Teachers'Perceptions. Unpublished MA thesis. Ohio University.

Christison, M. A. (1999). A Guidebook for Applying Multiple Intelligences Theory in the ESL/EFL Classroom. Burlingame, CA: Alta Book Center,

Christison, M. A., \& Kennedy, D. (1999). "Multiple Intelligences. Theory and Practice in Adult ESL”, in ERIC Digest. Retrieved November 8, 2008, from the World Wide Web: URL: http://www.cal.org/ncle/digests/MI.htm.

Gardner, H. (1983). Frames of mind. New York: Basic books.

Gardner, H. (1993). Multiple intelligences: The theory in practice. New York: Basic books.

Gardner, H. (1999). Intelligence reframed. New York: Basic Books.

Heacox, D. (2002). Differentiating Instruction in the Regular Classroom: How to Reach and Teach All Learners, Grades 3-12. Minneapolis, MN: Free Spirit Publishing.

Kýrkgöz, Y. (2010). "Telling ELT Tales out of School Catering for multiple intelligences in locallypublished ELT textbooks in Turkey", in Procedia Social and Behavioral Sciences, 3: 127130.

Lin, S. C. (2009). "Gender and Major Differences in Self-Estimates of Different Aspects of Gardner's Multiple Intelligences: A Study of the Undergraduate Pre-service Teachers in Taiwan", in Asian Social Science, 5: 3-14.

Marsh, C. (1997). Key concepts for understanding curriculum. London: Falmer Press.

Moran, S., \& Kornhaber, M., \& Gardner, H. (2006). "Orchestrating multiple intelligences", in Educational Leadership, 64: 22-27.

Nunan, D. (1988). The Learner-centred Curriculum. Cambridge: Cambridge University Press.

Özdilek, Z. (2010). "To what extent do different multiple intelligences affect sixth grade Students' achievement level on the particle model of matter", in Procedia Social and Behavioral Sciences, 4: 4858-4862.

Palmberg, R. (2001). "Catering for Multiple Intelligences in EFL Coursebooks”, in HLT Magazine, January 2002. Retrieved on November 9, 2009. URL:http://www.hltmag.co.uk/jan02/sart6.

Puchta, H., \& Rinvolucri, M. (2005). Multiple Intelligences in EFL Exercises for secondary and adult students. Cambridge University Press.

Razmjoo, A. S. (2009). "On The Relationship between Multiple Intelligences and Language Proficiency", in The Reading Matrix, 8(2): 155-174.

Riazi, A. M., \& Mosalanejad, N. (2010). "Evaluation of Learning Objectives in Iranian High-School 
and Pre-University English Textbooks Using Bloom's Taxonomy", in The Electronic Journal for English as a Second Language. 13(4): 1-16.

Richards, J. \& Rodgers, T. (2001). Approaches and methods in language teaching.Second Edition. Cambridge: CUP.

Saricaoglu, A., \& Arikan, A. (2009). "A study of multiple intelligences, foreign language success and some selected variables", in Journal of Theory and Practice in Education, 5 (2):110122.

Sauer, C. (1998). Developing a survey for Multiple Intelligences, in J.M. Reid (ed.), Understanding learning styles in the second language classroom. Upper Saddle River, NJ: Prentice Hall Regents, 100-106.

Serin, N., \& Serin. O., \& Yavuz, A. M., \& Muhammedzade, B. (2009). "The relationship between the primary teachers' teaching strategies and their strengths in multiple intelligences (Their multiple intelligence types) (Sampling: Izmir and Lefkosa)", in Procedia Social and Behavioral Sciences, 1: 708-712.

Snider, D. P. (2001). Multiple Intelligences Theory and Foreign Language Teaching. Unpublished doctoral dissertation, University of Utah.

Sözen, H., \& Sozen, M., \& Tekat, A. (2009). "Comparison of the profiles of the potential teachers in different disciplines based on multiple intelligences theory (Samsun City Sample)". Procedia Social and Behavioral Sciences, 1: 943-948.

Wu, S., \& Alrabah, S. (2009). "A cross-cultural study of Taiwanese and Kuwaiti EFL learning styles and multiple intelligences students". Innovations in Education and Teaching International, 46(4): 393-403.

Yenice, N., \& Aktamis, H. (2010). "Determination of multiple intelligence domains and learning styles of the teacher candidates", in Procedia Social and Behavioral Sciences, 2: 32743281 .

\section{Analyzed textbooks}

Afghari, A. (2002). English for the students of Persian Literature II. Tehran: SAMT publications. Aghvami, D. (2005). English for the students of accounting. Tehran: SAMT publications.

Al-hussaini, M., \& Jalili, M., \& Bahrami Navid, M. (2003). English for the students of theology and Islamic studies. Tehran: SAMT publications.

Azabdaftart, A. (2002). English for the students of Agriculture. Tehran: SAMT publications

Azmi, M. (2008). English for the students of Civil Engineering. Tehran: SAMT publications

Didari, R. \& Zia Hossaini, M. (2001). English for the students of Medicine. Tehran: SAMT publications

Faghih, E. (2006). English for the students of Physics. Tehran: SAMT publications.

Ghasemi, M. (2010). English for the students of Power \& Electronics Engineering.

Tehran: Jangal Publications.

Haghani, M. (2006). English for the students of Power, Electronics, Cotrol \& Communications. Tehran: SAMT publications.

Jalalipour, J. (2002). English for the students of Mechanical Engineering Fluid Thermal Approach. Tehran: SAMT publications.

Khajavi, D. \& Mamasani, S. ( 2005). English for Physical Education. Sabike Pub.

Nowruzi, M. \& Birjandi, P. (2001). English for the Humanities I. Tehran: SAMT publications. Sayed Mohammdi, Y. (2005). English for the students of General Psychology. Arasbaran Pub. 
Shahmirzadi, M., \& Birjandi, P.(2001). English for the students of Archaeology. Tehran: SAMT publications.

Shirvani, A. (2006). Legal Texts (Criminal Law) A Text Book For Law Students. Tehran: SAMT publications.

Zareinia, H. A., \& Soheili, M. (2007). English for Computer science students Mahad. Publications.

Zia Husseini, M. S., \& Zia Husseini, A. S. (2004). English for the students of Applied Physics. Tehran: SAMT publications. 